\title{
Briefing: Some recycling rates are more equal than others
}

David W. J. Greenfield BSc, PhD

Managing Director, SOcial, ENvironmental \& EConomic Solutions (SOENECS) Ltd, Burgess Hill, UK (corresponding author:

davidg@soenecs.co.uk)
Ryan Woodard BSC, PhD

Senior Research Fellow, University of Brighton, Brighton, UK

Debates surrounding the definition of waste streams and what construes recycling have been going on for decades. And it is a discussion that is unlikely to finish anytime soon.

\section{Background}

Under the Waste Framework Directive 2008 (EC, 2008), by 2020, the member states will need to 'prepare for reuse and the recycling of waste materials such as at least paper, metal, plastic and glass from households and possibly from other origins as far as these waste streams are similar to waste from households, shall be increased to a minimum of overall $50 \%$ by weight'. This has been widely interpreted as member states achieving a 50\% recycling rate for household waste by 2020 .

More recently, under the revised proposals set out in the European Commission Circular Economy Package, there are targets to recycle $65 \%$ of municipal waste by 2030 , and a binding target to reduce landfill to a maximum of $10 \%$ by 2030 (EC, 2015a). Similarly, resource efficiency and waste management feature heavily within the United Nations Sustainable Development Goals with a target to reduce substantially waste generation through prevention, reduction, reuse and recycling by 2030 (UN, 2015).

With policy documents proposing higher recycling rate targets there is increasing scrutiny on how waste streams are defined and how recycling rates are being calculated. Of particular concern is the threat of financial penalties for failing to hit targets; there are already examples of member states being issued with fines for non-compliance with European waste regulations. In July 2015, the European Court of Justice ruled against Italy for a second time for the breach of waste legislation in the Campania Region. They were issued a lump sum penalty of $€ 20$ million and fines of $€ 120000 / d$ until they complied with the court's first judgement of 2010 (CJEU, 2015). The following month the European Commission announced they would be taking Spain to the European Court of Justice as they had failed to close, seal and restore 61 illegal sites (EC, 2015b). In June 2016, Slovakia was referred to the European Court of Justice for failing to act following a decision in 2013 that the Žilina-Považský Chlmec landfill was operating without a plan to protect the environment and public health. The European Commission are lobbying for a penalty of $€ 939000$ and a daily fine of $€ 6793$ (EC, 2016). It has long been rumoured that the member states could face similar financial penalties for not hitting recycling targets - in the UK there has been the unsubstantiated figure in the written press of a $£ 500000$ fine/d for not hitting the 2020 target (Gosden, 2014). Interestingly, in Wales individual local authorities have been threatened with fines of $£ 200 / \mathrm{t}$ for not hitting the national statutory recycling targets, although to date this has not come to fruition (NAFW, 2014).

\section{Varying definitions of waste streams}

There are numerous publications that highlight the difficulties in comparing waste management practices globally due to varying definitions being applied to waste streams (Chalmin and Gaillochet, 2009; RRFDDA, 2004; UNEP, 2010). The definition of municipal solid waste (MSW) differs across countries, many including varying levels of waste from households, commerce, industry, construction and institutional waste such as schools, government offices and hospitals in their definition of MSW (EEA, 2013; GA, 2009; Terazono et al., 2005; USEPA, 2013; Wilson et al., 2001). As such published data on waste arisings and progression towards targets will be based on inconsistent information. Moreover, many countries simply do not have the basic systems in place to collect reliable and consistent data on waste arisings or how it is being managed. The UK is a case in point - whereas the authors have reliable data on household waste, there is great uncertainty on the quantities and management of commercial and industrial waste and construction waste.

\section{Reported recycling rates across EU member states}

The Chartered Institution of Waste Management (CIWM) commissioned SOENECS in partnership with the University of Brighton to research how EU member states were progressing towards meeting the 2020 recycling target, how they defined waste streams and how they calculated their 
recycling rate. The research highlights that there is significant variation in practice and definitions across member states which in turn influences their reported performance. Some of this uncertainty stems directly from European Commission guidance.

The Commission Decision of 18 November 2011 established rules for verifying compliance with the Waste Framework Directive targets and contained four different methods for calculating recycling rates within member states, presumably to allow for existing member state practice (EC, 2011). Method 1 focuses specifically on the recycled levels of paper, metal, plastics and glass within the household waste stream. Method 2 adopts a similar approach but includes other single-stream recycled materials. Method 3 looks at household waste per se, and finally method 4 focuses on the entire municipal waste stream. As such the method adopted by member states will significantly influence the recycling rate being attained. The authors' analysis suggests that method 2, used by 14 member states, and method 4 , used by eight member states, are the most common calculations adopted.

Similarly, the kind of materials and waste streams included within the definition of household waste or MSW will have an impact on the cycling rates. Take, for example, the fourth method which includes all materials contained within MSW. On the basis of the authors' analysis, there is a significant variation across member states in their definition of MSW. For example, some states exclude packaging which has been collected by the private sector while others include commercial waste collected by private contractors. Some member states also include bottom ash and metals from the backend of energy recovery facilities and composting at home within their recycling rate calculation.

\section{Comparing apples with apples?}

To understand in greater detail the sensitivity that these variables could have on reported recycling rates, a modelling exercise was conducted for nine European municipalities comparing their recycling rates. Following discussions with key industry bodies (CIWM, The Association of Directors of Economy, Planning and Transport and Local Authority Recycling Advisory Committee), a shortlist of recommended municipalities was developed, who would be co-operative but also represent a range of municipalities. These municipalities were formally contacted and invited to participate. Municipalities were asked to complete a questionnaire and data table documenting waste arisings and management within their jurisdiction. This included the following.

- Details on 15 primary and 67 secondary materials or items and whether they are included in their definition of household waste and MSW.
Weight data on how they managed (e.g. recycled, sent to energy recovery facilities, landfilled) 15 primary categories of materials or items - and where possible a more detailed breakdown.

- A breakdown of residual waste composition.

On the basis of this information, it was possible to model overall arisings and to calculate recycling rates across a range of scenarios. The intention was to calculate recycling performance based on the four methods described above. A problem faced was trying to isolate household data from municipal data - this was not possible so all calculations were based on MSW data supplied by the participating municipalities. As such, four hybrid scenarios for modelling recycling rates were developed as set out in Table 1. Of particular interest was scenario 4 which included metals and bottom ash recovered from the energy recovery facilities plus street sweepings in the recycling rate calculation. The authors' review had shown that Germany, France, Sweden, Scotland and Wales have already included bottom ash and the recovered metal from energy recovery facilities towards recycling targets. As Wales and Scotland already count recycled bottom ash and metals towards their recycling rates, the Local Government Association states that if this material was appropriately verified and counted in England as recycling, it could contribute up to an additional $7 \%$ to the recycling rate by 2020 (LGA, 2014). Therefore, it was interesting to model the potential impact of this at the municipal level.

\section{Results}

Table 1 collates the recycling rates from each scenario including the difference between the highest and lowest recycling rates for each municipality. The data show that there is a $5 \cdot 4 \%$ difference between the average highest (scenario 2 ) and lowest (scenario 3) recycling rates. Specifically, for individual municipalities when applying the four scenarios the biggest difference was $14.9 \%$ (municipality 1 ) and the lowest $5.9 \%$ (municipality 8 ). The highest recycling rate attained was $63 \cdot 7 \%$ and the lowest was $38 \cdot 5 \%$.

The results show a significant difference in the recycling rate depending on the calculation adopted. Ticks in Table 1 highlight under which scenarios the municipality would successfully meet the $50 \%$ recycling target for 2020 . For four of the municipalities hitting the target was dependent on the scenario applied, with three municipalities meeting the target under every scenario and two failing to hit the target under any scenario.

Of course the waste management system adopted for each municipality would directly influence their performance in each scenario. For example, municipalities 6 and 7 see a $7 \cdot 3$ and $8 \cdot 5 \%$ increase, respectively, when applying scenario 2 compared with scenario 1 . This is due to the municipalities adopting bio-waste collections which would not be included in 


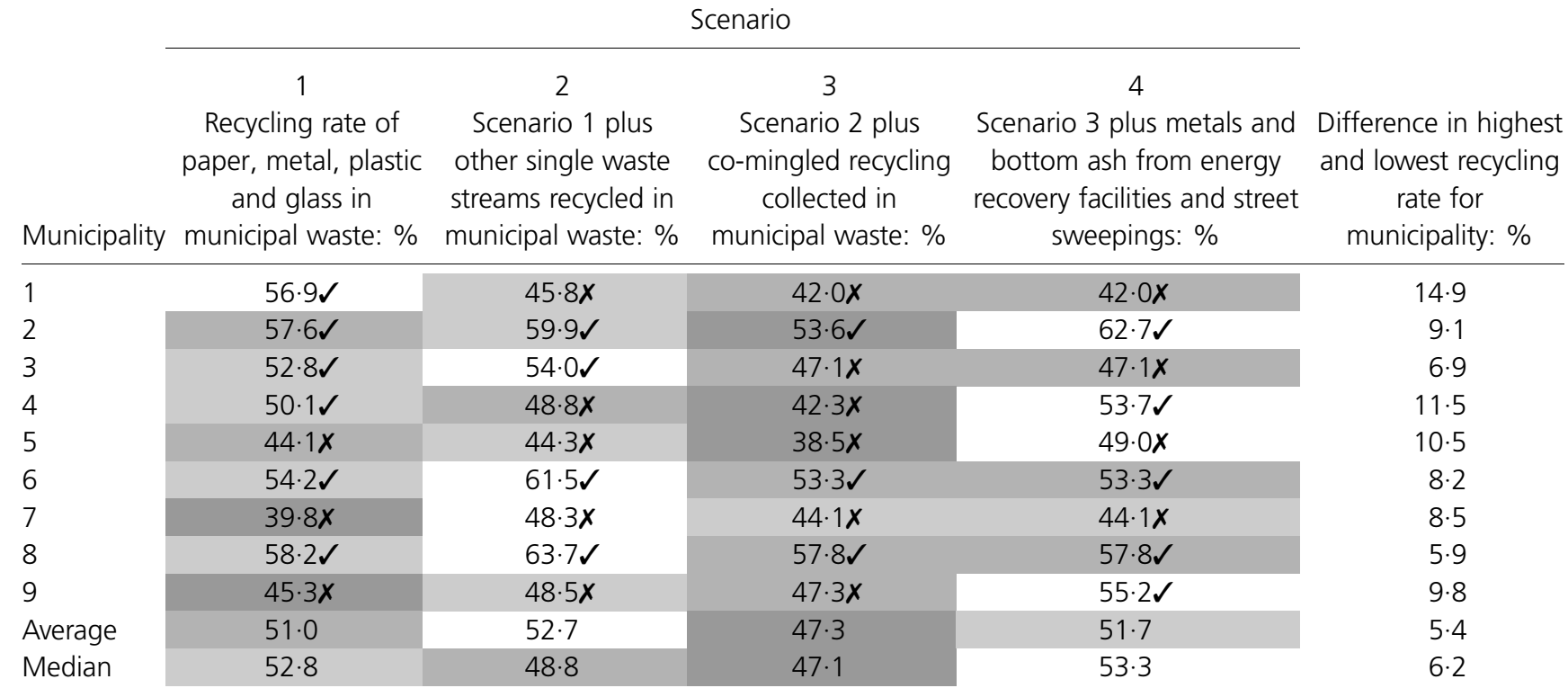

Table 1. Overview of recycling rates from each scenario (lighter shaded cells show the highest rate and darker cells the lowest for each municipality. Tick/cross denotes if under the scenario the $50 \%$ recycling rate for 2020 would be met)

scenario 1. Similarly, four municipalities (2, 4, 5 and 9) see an average increase in recycling of $9.8 \%$ from scenario 4 over scenario 3 as they send residual waste to energy recovery facilities and under scenario 4 outputs from this process are included in the recycling rates.

\section{Discussion and next steps}

The research provides significant insight into the challenges of comparing recycling rates between member states. From a purely statistical perspective, the different data parameters, definitions, interpretations and methodologies that are presently being employed limit the potential for accurate recording and comparing recycling performance across member states. Ultimately, these issues not only impact on the way recycling rates are calculated and reported in the context of the 2020 Waste Framework Directive targets, they also highlight the need for more robust definitions, calculation methodologies and data capture frameworks to underpin any waste targets in the new Circular Economy Package. More widely, it could be argued that globally a more consistent approach is needed to help measure progress against the sustainable development goals.

The research joins a body of evidence that calls for improved data and consistency across member states. It is pleasing to see that the EU is taking note and as set out in the Circular Economy Package they are working on developing simplified and improved definitions and harmonised calculation methods for recycling rates throughout the EU. A significant challenge to future harmonisation of calculation methods may be the exit of the UK from the EU and any future rolling back of reporting or definitional change.

The challenge for the future policy direction can only be based on sound data measurement and comparability. Given below are some points for further consideration.

- The inclusion of post-treatment fractions in recycling rate calculations - for example, compost-like outputs from anaerobic digestion and mechanical biological treatment facilities, and bottom ash from energy recovery facilities.

- The point at which recycling is counted - - that is, on the basis of the tonnage after the primary sorting and processing stage or the tonnage at the reprocessing stage, where additional sorting and contamination removal may have taken place.

- Even though the recycling rate includes 'prepare for reuse' this is rarely considered in recycling calculations and requires further rigour and clarification of how reuse is calculated and reported.

- Consideration of how commercial waste is included in the municipal waste definition. Often commercial waste is included if collected by the public sector but excluded when handled by the private sector thus skewing figures. 
- The overall reliability and rigour of data being submitted by member states on their recycling practice.

\section{Acknowledgement}

The authors acknowledge all municipalities for submitting their data and the CIWM for funding the research.

\section{REFERENCES}

Chalmin P and Gaillochet C (2009) From Waste to Resource: World Waste Survey 2009. Economica, Paris, France.

CJEU (Court of Justice of the European Union) (2015) Press release No 86/15 Luxembourg, 16 July 2015 - as a result of its incorrect application of the Waste Directive in the region of Campania, Italy is ordered to pay a lump sum of $€ 20$ million and a daily late-payment penalty of $€ 120000$. Court of Justice of the European Union, Luxembourg.

EC (European Communities) (2008) Directive 2008/98/EC of the European Parliament and of the Council of 19 November 2008 on waste and repealing certain Directives. Official Journal of the European Communities L312/3.

EC (2011) Commission Decision of 18 November 2011 establishing rules and calculation methods for verifying compliance with the targets set in Article 11(2) of Directive 2008/98/EC of the European Parliament and of the Council. Official Journal of the European Communities L 310/11.

EC (2015a) Closing the loop - an EU action plan for the Circular Economy. European Commission, Brussels, Belgium. See http://ec.europa.eu/environment/circulareconomy/index_en.htm (accessed 10/10/2016).

EC (2015b) Press Release Commission refers Spain to Court over illegal landfills Brussels, 16 July 2015. European Commission, Brussels, Belgium. See http://europa.eu/rapid/ press-release_IP-15-5354_en.htm (accessed 10/10/2016).

EC (2016) Press Release Commission proposes to fine SLOVAKIA in connection with landfill in Žilina. European Commission, Brussels, Belgium. See http://europa.eu/rapid/ press-release_IP-16-2099_en.htm (accessed 10/10/2016).

EEA (European Environment Agency) (2013) Managing Municipal Solid Waste - A Review of Achievements in 32 European Countries. European Environment Agency, Copenhagen, Denmark, Report No 2/2013.

GA (Green Alliance) (2009) Landfill Bans and Restrictions in the EU and US. Green Alliance, London, UK, Report No WR1202.

Gosden E (2014) Why the UK could face millions of pounds in EU recycling fines - for using less paper. Daily Telegraph, 18 November. See http://www.telegraph.co.uk/ news/earth/businessandecology/recycling/11239353/Whythe-UK-could-face-millions-of-pounds-in-EU-recyclingfines-for-using-less-paper.html (accessed 12/10/2016).
LGA (Local Government Association) (2014) Meeting EU Recycling Targets. Local Government Association, London, UK.

NAFW (National Assembly for Wales) (2014) Environment and Sustainability Committee: Inquiry into Recycling in Wales. National Assembly for Wales, Cardiff, Wales, UK.

RRFDDA (Resource Recovery Forum and David Davies Associates) (2004) High Diversion of Municipal Waste: Is It Achievable?. Resource Recovery Forum, Skipton, UK.

Terazono A, Moriguchi Y, Yamamoto YS et al. (2005) Waste management and recycling in Asia. International Review for Environmental Strategies 5(2): 447-498.

UN (United Nations) (2015) Resolution adopted by the General Assembly on 25 September 2015 70/1 Transforming our world: the 2030 Agenda for Sustainable Development. Journal of the United Nations, see http://www.un.org/ Docs/journal/En/20150925e.pdf?En/20150925E (accessed 23/11/2016).

UNEP (United Nations Environment Programme) (2010) Waste and Climate Change - Global Trends and Strategy Framework. United Nations Environment Programme, Nairobi, Kenya, DTI/1314/JP.

USEPA (United States Environmental Protection Agency) (2013) Municipal Solid Waste in the United States 2011 Facts and Figures. United States Environmental Protection Agency, Washington, DC, USA, EPA530-R-13-001.

Wilson EJ, McDougall FR and Willmore J (2001) Euro-trash: searching Europe for a more sustainable approach to waste management. Resources, Conservation and Recycling 31(4): $327-346$.

\section{HOW CAN YOU CONTRIBUTE?}

To discuss this briefing, please email up to 500 words to the editor at journals@ice.org.uk. Your contribution will be forwarded to the author(s) for a reply and, if considered appropriate by the editorial board, it will be published as discussion in a future issue of the journal.

Proceedings journals rely entirely on contributions from the civil engineering profession (and allied disciplines). Information about how to submit your paper online is available at www.icevirtuallibrary.com/page/authors, where you will also find detailed author guidelines. 